\title{
VARISKÝ VRÁSOVÝ SYSTÉM ODKRYTÝ V LOMU PODHŮRA (SV. OKRAJ ČESKÉHO MASIVU, KRA MALENÍKU)
}

\author{
Variscan fold system exposed in the Podhůra quarry (NE part of the Bohemian Massif, Block \\ of Maleník)
}

Josef Havír

Ústav fyziky Země, PřF MU, Tvrdého 12, 60200 Brno; e-mail: havir@ipe.muni.cz

(25-13 Přrov)

Key words: Moravian-Silesian Palaeozoic, orientation of structures, folds

\begin{abstract}
In the Podhira quarry situated in the SW part of the Block of Maleník southwards of Lipník nad Bečvou, the Culm sediments influenced by Variscan fold-thrust system are exposed. Geometry of the Variscan folds was studied in more detail at five sites (A to E), where hinge zones of these folds were well visible. The ESE-vergent system of asymmetric close folds of $k m$ order represents dominant tectonic structure observed in the Podhura quarry. Synform of such fold of km order was studied at site A, antiform hinge zone was exposed at sites $B$ and $C$. At the sites $D$ and $E$, synform and antiform hinge zones of smaller open folds, of 100 meter order, were studied. Fold axes were predominantly NNE-SSW to NE-SW oriented, only at site E the N-S orientation of fold axis was found. These orientations are the same as predominant orientation of fold axes on the eastern margin of the Nizký Jeseník region. On the contrary, significant differences were found in the values of dip of axial planes and fold limbs. In the Podhura quarry, the axial planes are subvertical or steeply WNW to NW dipping. In the case of fold of km order, one limb is subvertical, another limb is moderately WNW to NW dipping. It means that, compared to fold geometry on the eastern margin of the Nizký Jesenik region, the system of folds of $\mathrm{km}$ order studied in the SW part of the Block Malenik is westward to northwestward tilted steeper by at least $40^{\circ}$.
\end{abstract}

Úvod

V rámci geologického mapování na listu 25-132 Lipník n. Bečvou byl v listopadu 2015 navštiven lom Podhůra situovaný v kulmských horninách kry Maleníku, jižně od Lipníku n. Bečvou (obr. 1). V lomu je velmi dobře odkrytá cást systému variských vrás ráádově kilometrových rozměrů. Cílem tohoto př́ispěvku je stručně informovat o charakteristice odkrytých vrás a nastínit základní body týkajíć se porovnání geometrie těchto vrás s variskými vrásami sledovanými na jiných místech kulmu sv. cásti Českého masivu.

\section{Geologie studované oblasti}

V rámci lomu Podhưra, který se nachází v jz. části kry Maleníku, jsou těženy kulmské hradecké droby stáŕi svrchního visé (Dvořák 1994). Zmíněné droby jsou součástí hradecko-kyjovického souvrství. Představují tak součást variského flyše odkrytého v severovýchodní ćásti Českého masivu zejména v prostoru Nízkého Jeseníku.

Kulmské sedimenty východního okraje Nízkého Jeseníku i kry Maleníku jsou zvrásněny asymetrickými vrásami řádově kilometrových rozměrů s východní vergencí a s orientací os převážně ve směru SSV-JJZ (Kumpera 1983). Tyto vrásy př̀edstavují dominantní, v terénu velmi dobře patrný, prvek vrásovo-násunové stavby (viz Grygar - Vavro 1995). Kombinace vrás a rozsáhlých násunů je dokládána např. seismickými profily interpretovanými Čížkem a Tomkem (1991).

Paleozoikum kry Maleníku je pak od vlastního prostoru Nízkého Jeseníku odděleno Moravskou bránou vyplněnou neogenními sedimenty karpatské předhlubně. Na jihu kry Maleníku jsou na jednotky Českého masivu nasunuty západokarpatské flyšové př́íkrovy. Horniny náležející západokarpatským př́krovům se nachází také pod neogenními sedimenty v prostoru Moravské brány (Krejčí et al. 2002).

\section{Geometrie vrásových ohybů v lomu Podhůra}

V lomu Podhůra bylo pozorováno několik vrásových ohybů a to jak charakteru synformy tak i antiformy. Detailněji byly sledovány vrásové ohyby na pěti vybraných místech označených A až E (obr. 2 a 3). Orientace os vrás a osních rovin byly vypočteny $z$ orientací ploch vrstevnatosti měřných $\mathrm{v}$ ramenech sledovaných vrás. Osy všech sledovaných vrás jsou jen mírně ukloněné, orientované ve směru SSV-JJZ až SV-JZ (vrásové ohyby A až D), respektive ve směru S-J (vrásový ohyb E), osní roviny jsou bud' subvertikální, nebo strmě ukloněné $\mathrm{k}$ ZSZ až SZ.

Vrásový ohyb A reprezentuje synformu velké tektonické vrásy, odpovídající ráádově kilometrovým vrásám již výše zmiňovaného východovergentního vrásovo-násunového systému. Východní rameno je středně ukloněné, sklony spádnic ploch vrstevnatosti se pohybují mezi $34^{\circ}$ a $45^{\circ}$. Vrásový ohyb je odkryt při východním okraji lomu, a proto je východní rameno diskutovaného vrásového ohybu dobře sledovatelné $\mathrm{v}$ lomové stěně pouze $\mathrm{v}$ délce několika desítek metrů, nepochybně ale pokračuje dále k východu za hranice lomu. Západní rameno je strmé až subvertikální. $V$ prostoru lomu vytváŕí více než 50 metrů širokou subvertikální zónu vyznačující se převážně velmi strmými úklony ploch vrstevnatosti. Místy jsou v diskutovaném subvertikálním rameni rozeznatelné tektonické šupiny, v jejichž rámci lze pozorovat sedimenty deformované vrásami menších ( $\mathrm{v}$ závislosti na litologii rádově 


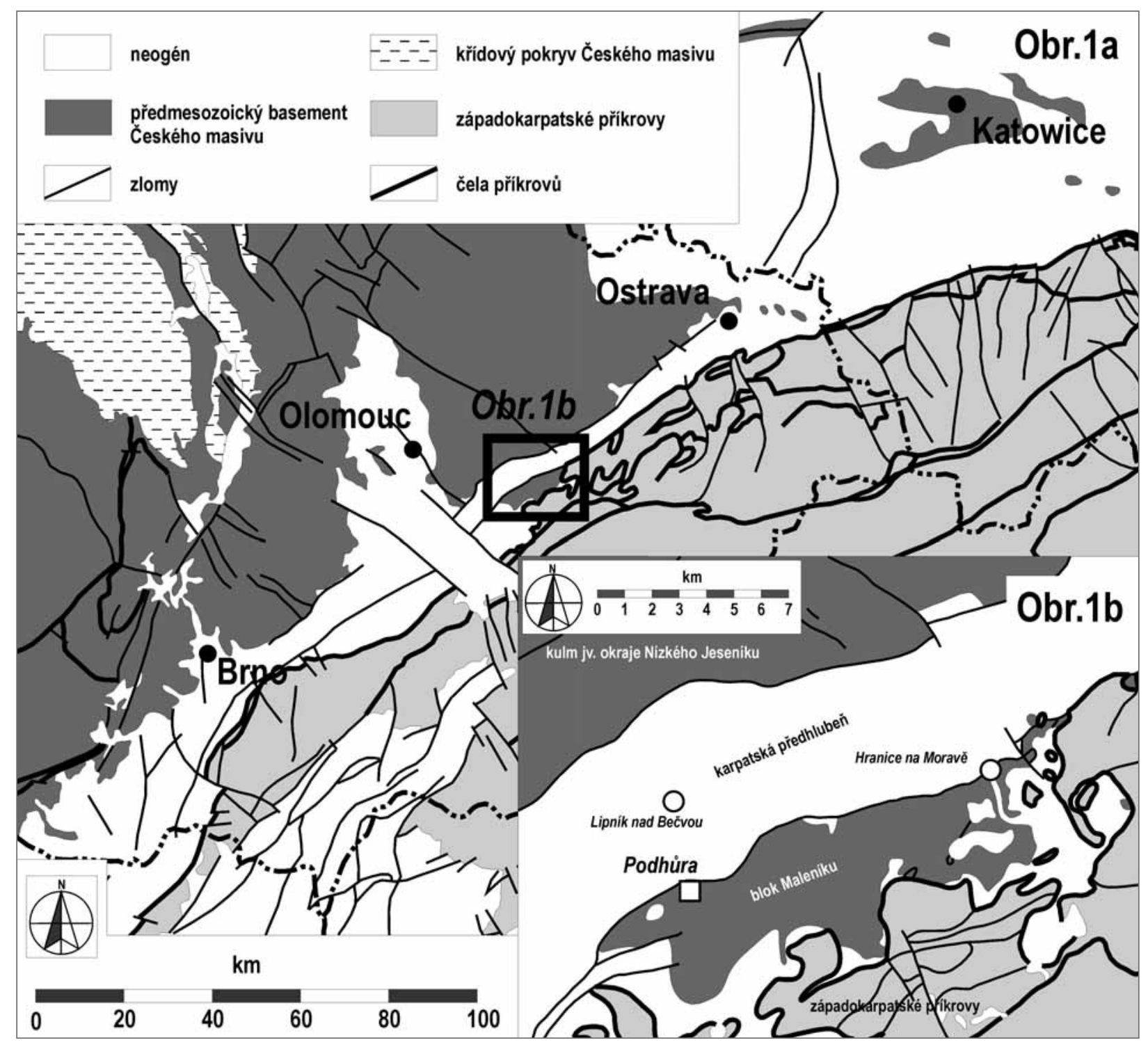

Obr. 1: a - Schematická geologická mapa východní ćásti Českého masivu, (sestaveno a modifikováno podle Kodyma a kol. 1967 a Mahel'a a kol. 1973); b - schematická geologická mapa s vyznačenou pozicí lomu Podhůra (podle Rotha 1990, zjednodušeno). Fig. 1: a- Geological scheme of the NE part of the Bohemian Massif (compiled and modified after Kodym et al. 1967 and Mahel et al. 1973); b - geological scheme with marked out location of the Podhůra quarry (after Roth 1990, simplified).

metrových či decimetrových) rozměrů. Orientace osy vrásy vypočtená pro ohyb A je 210/12, osní rovina se uklání pod úhlem $65^{\circ} \mathrm{k}$ ZSZ až SZ. Ohyb v zámkové oblasti je náhlý, zámková oblast má většinou řádově jen metrové rozměry. Ve srovnání s rozměry ramen je tedy zámková oblast synformního ohybu velmi malá.

Vrásové ohyby B a C představují antiformu velké vrásy odpovídající řádově kilometrovým vrásám východovergentního vrásovo-násunového systému. Východní rameno je tvořeno subvertikální zónou diskutovanou již při popisu vrásového ohybu A. Západní rameno, které je porušené zakřivenou dislokací výrazně se projevující zejména v místě ohybu $\mathrm{C}$, je pak středně ukloněné, sklony ploch vrstevnatostí se pohybují v části $\mathrm{B} v$ rozmezí od $23^{\circ}$ do $26^{\circ}$, v části $\mathrm{C}$ byla vrstevnatost měřena $\mathrm{v}$ západním rameni pouze na jednom místě a její sklon byl $56^{\circ}$. Oproti synformnímu ohybu A je zámková oblast antiformního ohybu zřetelně větší a to jak v části B tak i v části C. K po- stupné změně orientace ploch vrstevnatosti ze subvertikálních úklonů ve východním rameni po stř̌ední úklony v západním rameni dochází v průběhu řádově desítek metrů. Orientace vrásové osy (213/3 v př́padě ohybu B; $213 / 18$ $\mathrm{v}$ př́padě ohybu C) je blízká orientaci osy synformního ohybu A. Osní rovina se opět uklání strmě k ZSZ až SZ, úklon spádnice osní roviny je podobný ( $v$ případě ohybu B) nebo o něco strmější (v př́ípadě ohybu $C$ ) ve srovnání s osní rovinou synformního ohybu A (sklon spádnice je $62^{\circ}$ $\mathrm{v}$ prrípadě ohybu $\mathrm{B}$ a $86^{\circ} \mathrm{v}$ prrípadě ohybu $\mathrm{C}$ ). Meziramenní úhel všech tř́i dosud popsaných vrásových ohybů $(\mathrm{A}, \mathrm{B}, \mathrm{C})$ se pohybuje $\mathrm{v}$ rozmezí $45^{\circ}$ až $70^{\circ}$ a popisované struktury tak lze označit jako sevřené vrásy.

Vrásové ohyby D a E reprezentují ohyby rozevřených vrás řádově stametrových rozměrů komplikujících průběh stř̌edně ukloněného ramene větší, řádově kilometrové vrásy. Ohyb D je synformní, orientace vrásové osy (225/9) je v tomto místě podobná orientaci os vrásových ohybů A, 


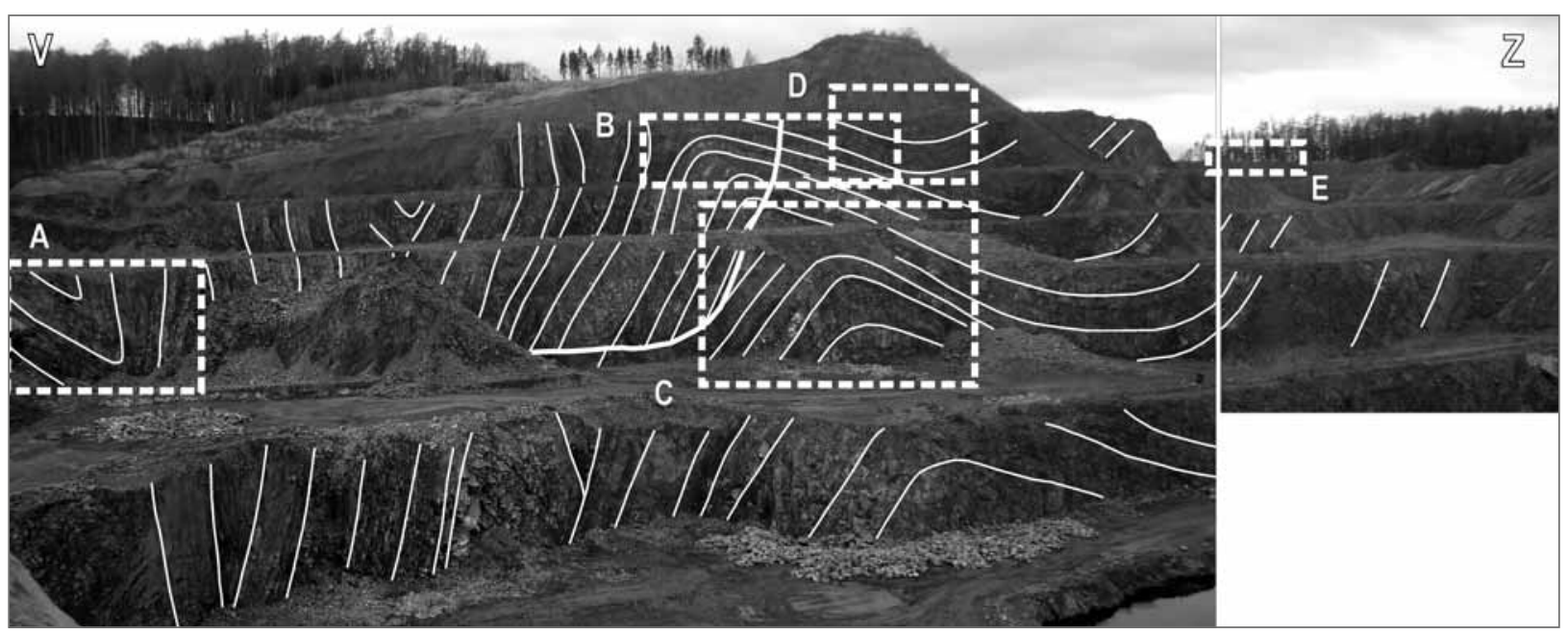

Obr. 2: Celkový pohled na lom Podhůra od severu s vyznačenými místy sledovaných vrásových ohybů A až E (obdélníky omezené přerušovanou čarou), jejichž detailní schématické nákresy jsou na obrázku 3. Bílými čarami jsou zvýrazněny průměty ploch vrstevnatosti v lomové stěně, silná bílá čára vyznačuje dislokaci porušující vrásové ohyby B a C.

Fig. 2: General view of Podhůra quarry from the north with marked sites of observed fold hinge zones A to E (rectangles limited by dashed lines) whose detail schemes are plotted in figure 3 . White lines accentuate bedding plane projections into quarry wall, bold white line is a dislocation faulting the folds B and C.

B a C, osní rovina se uklání pod úhlem $74^{\circ} \mathrm{k}$ SZ. Ohyb E je oproti tomu antiformní, orientace osy je severo-jižní (0/11) a osní rovina je subvertikální (úklon $86^{\circ}$ k východu).

Předběžné srovnání s geometrií kulmských vrás na jiných místech sv. okraje Českého masivu

V lomu Podhůra lze v důsledku zvrásnění kulmských sedimentů vrásami řádově kilometrových a stametrových rozměrů sledovat střídání zón $s$ převládající středními úklony ploch vrstevnatostí a zón s převládající strmou až subvertikální vrstevnatostí. Podobný charakter lze pozorovat také $\mathrm{v}$ dalších částech kry Maleníku, západně od Týna n. Bečvou (Havír 2003; Havír a kol. 2003), strmé až subvertikální orientace $\mathrm{v}$ jednom $\mathrm{z}$ vrásových ramen byly dokumentovány také např. v lomu u Paršovic (Otava - Havír 2006). I když je zapotřebí interpretovat strukturní měření zejména v severní části kry Maleníku se zvýšenou opatrností z důvodu možného vlivu svahových pohybů na současnou orientaci strukturních prvků, podobnost orientace základních prvků variské vrásové stavby pozorované $\mathrm{v}$ lomu Podhưra $\mathrm{s}$ vrásovou stavbou kulmských sedimentů dosud sledovanou na dalších místech kry Maleníku je zjevná.

Oproti tomu již hrubé porovnání diskutované vrásové stavby z lomu Podhůra s vrásami studovanými na východním okraji Nízkého Jeseníku ukazuje jak významné podobnosti, tak i významné rozdíly. Vrásová stavba byla na východním okraji Nízkého Jeseníku v minulých letech detailněji studována na řadě lokalit, na kterých byly vrásové ohyby velmi dobře odkryty, např. v lomech Hrabůvka, Olšovec, Nejdek (Havír 2003; Havír a kol. 2003), ve štolách jižně od Oder (Haviř 2003), v několika opuštěných lomech sv. od Oder (Havír - Gilíková 2007) či v lomu Jakubčovice (Havír 2001).

K významným podobnostem patří zejména tvar vrásových struktur odpovídajících sevřeným řádově kilometrovým vrásám. Také u řádově kilometrových výcho- dovergentních vrás na východním okraji Nízkého Jeseníku byl pozorován rychlý ohyb vrstev v zámkových oblastech (především v prrípadě synforem), jejichž rozměry jsou malé (řádově srovnatelné s mocností ohýbaných vrstev) ve srovnání s délkou vrásových ramen (Havíř 2003; Havír a kol. 2003; Havír - Gilíková 2007). Mají stejný tvar, jaký byl pozorován $\mathrm{v}$ prŕṕpadě synformního ohybu A v lomu Podhůra.

Druhou významnou podobností je podobnost v orientaci vrásových os. Subhorizontální až mírně ukloněné osy orientované ve směru S-J až SV-JZ jsou charakteristické jak pro vrásy pozorované v lomu Podhůra, tak i pro vrásové struktury sledované v různých místech východního okraje Nízkého Jeseníku.

Naopak zřetelný rozdíl lze sledovat v případě sklonů osních rovin a ramen vrás. Pro východní okraj Nízkého Jeseníku je charakteristické, především pokud jde o řádově kilometrové východovergentní vrásy, že jedno vrásové rameno je překocené, přičemž plochy vrstevnatosti v něm mají převážně stř̌ední úklony, zatímco druhé rameno je v nepřekocené poloze a subhorizontální či jen mírně ukloněné. Oproti tomu v lomu Podhůra byly, jak bylo popsáno výše, zjištěny strmé až subvertikální úklony v případě vrásového ramene odpovídajícímu svou pozicí a charakterem mírně ukloněnému a překocenému rameni vrás ve východní části Nízkého Jeseníku. Podobně druhé rameno, odpovídající svou pozicí subhorizontálnímu rameni vrás sledovaných na východním okraji Nízkého Jeseníku, se v lomu Podhůra vyznačuje převážně středními úklony ploch vrstevnatostí. Důsledkem odlišných úklonů ramen vrás jsou také odlišné úklony osních rovin sledovaných v lomu Podhůra a na východním okraji Nízkého Jeseníku. Zatímco na východním okraji Nízkého Jeseníku se osní roviny sevřených východovergentních řádově kilometrových vrás uklánějí k západu až severozápadu pod mírnými až středními úhly, osní roviny sledované v lomu Podhůra 


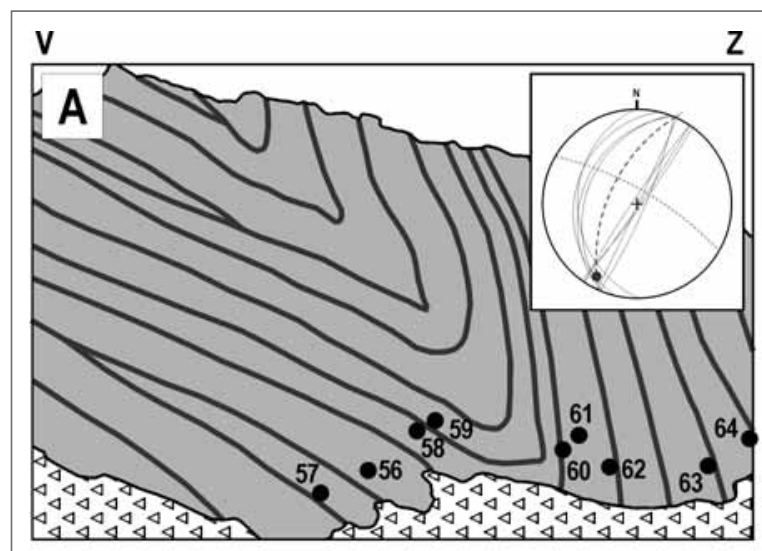

V

Z

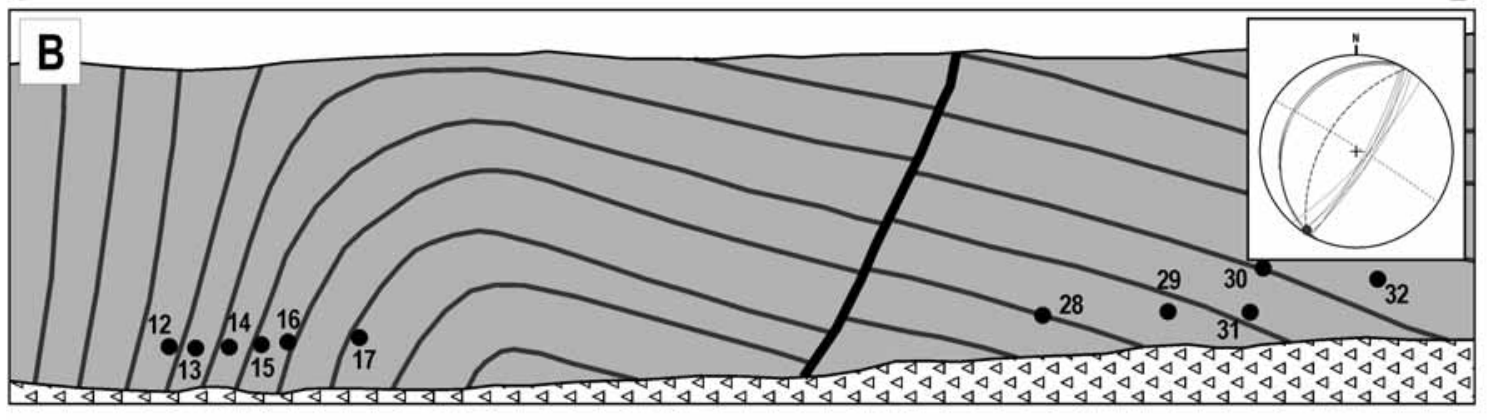

V

Z V

Z
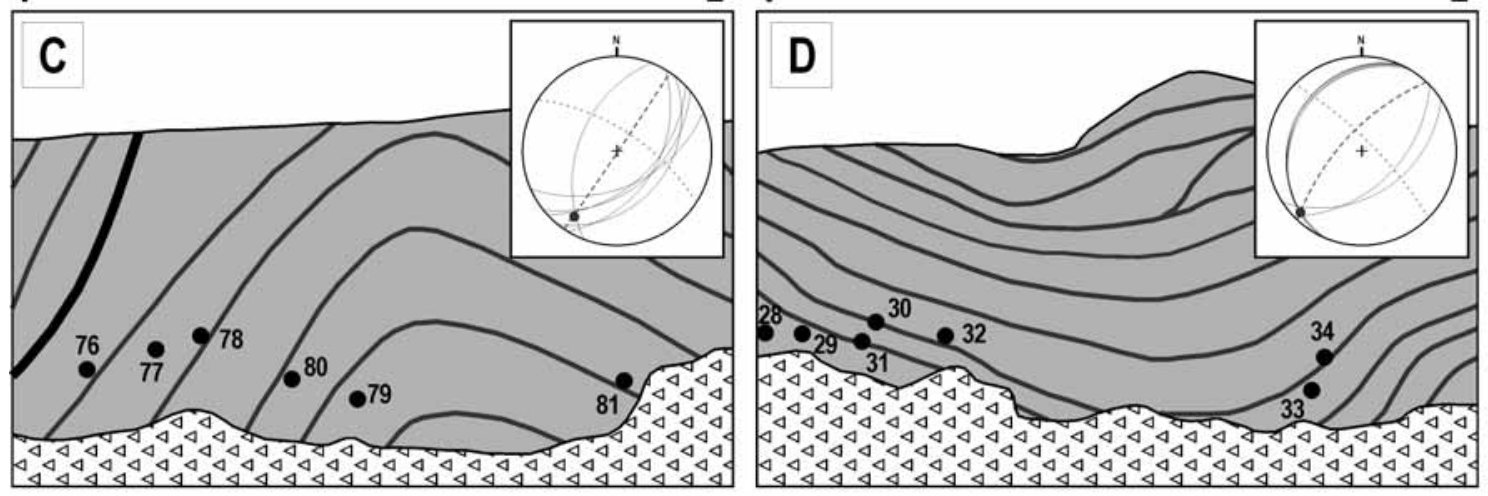

V

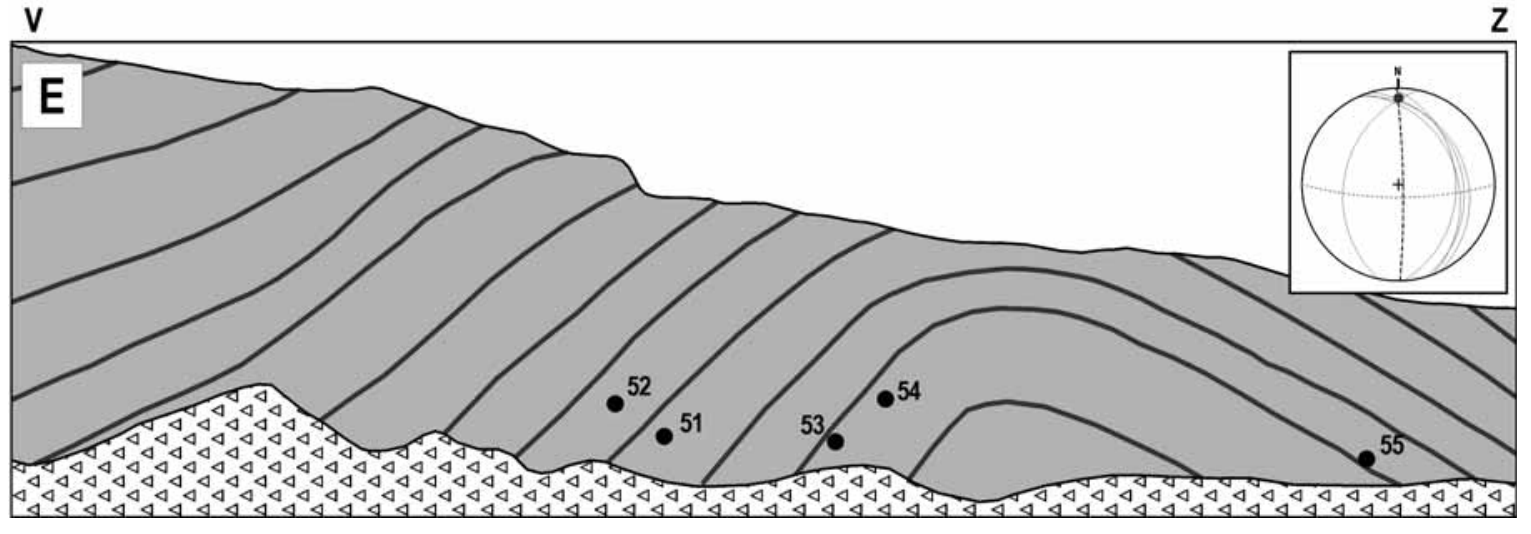

Obr. 3: Schematické nákresy vrásových ohybů A až E (tmavě šedé linie - plochy vrstevnatosti; silné černé linie - významné dislokace; černá kolečka - přibližná místa měření ploch vrstevnatosti využitých k výpočtu orientace vrásových os a vrásových osních rovin; šedou barvou je vyznačena lomová stěna) a grafy (Lambertova projekce, spodní polokoule) znázorňující orientaci ploch vrstevnatosti (nepřerušované velké oblouky), vrásových os (šedá kolečka), osních rovin vrás (přerušované velké oblouky) a ploch kolmých na vrásové osy (tečkované velké oblouky).

Fig 3: Schemes of the fold hinge zones A to E (dark grey lines - bedding planes; bold black line - dislocation; black circles - approximate points of bedding orientation measurements used for calculation of orientations of fold axes and axial planes; grey colour shows quarry wall) and graphs (Lambert projection, lower hemisphere) displayed orientations of bedding planes (continuous great circle arcs), fold axes (grey circles), axial planes (dashed great circle arcs) and plane perpendicular to fold axes (dotted great circle arcs). 
mají sice podobné azimuty směru, ale jejich úklony jsou strmé až subvertikální.

Vrásový systém pozorovaný v lomu Podhůra tedy svým charakterem a orientací vrásových os dobře koresponduje s tvarem vrás i orientací os vrásovo-násunového systému na východním okraji Nízkého Jeseníku. Celý vrásový systém v lomu Podhưra (a také v dalších místech v kulmských jednotkách kry Maleníku) je však oproti vrásovo-násunovému systému na východním okraji Nízkého Jeseníku ukloněn k západu až severozápadu, a to nejméně o $40^{\circ}$.

\section{Závěr}

V lomu Podhůra byly pozorovány vrásové ohyby jednak systému řádově kilometrových východovergentních vrás a jednak řádově stametrové rozevřené vrásy komplikující stř̌edně ukloněné rameno větší, řádově kilometrové vrásy. Orientace vrásových os (S-J až SV-JZ) je v dobré shodě s převažující orientací vrásových os v kulmských sedimentech na východním okraji Nízkého Jeseníku. Výrazně odlišné jsou ale sklony vrásových ramen a os- ních rovin. Vrásový systém pozorovaný v lomu Podhůra je oproti vrásovo-násunovému systému na východním okraji Nízkého Jeseníku ukloněn $\mathrm{k}$ západu o nejméně $40^{\circ}$ strměji. Příčiny takového úklonu kulmských jednotek jihozápadní části kry Maleníku oproti kulmu východního okraje Nízkého Jeseníku by bylo možné hledat hypoteticky jak ve variských, tak i v povariských procesech, mimo jiné např. v procesech spjatých s neogenní kompresí spojenou s dosouváním západokarpatských př́krovů, jejíž projevy byly v minulosti doloženy také př́mo v lomu Podhůra (Havír - Otava 1995). Dostatečně průkazné doklady o stáří a prríčinách rotace vedoucí k pozorovanému úklonu vrásové stavby ale zatím $\mathrm{k}$ dispozici nejsou.

\section{Poděkování}

Príspèvek vznikl v rámci prací na projektu ČGS číslo 321186 „Základní geologické mapování České republiky 1 : 25000 pro roky 2014-2018, oblast střední Morava“. Autor děkuje obèma recenzentům (RNDr. Jiřimu Otavovi, CSc. a RNDr. Jiřímu Rezovi, Ph.D.) za jejich připomínky.

Literatura

Čížek, P. - Tomek, Č. (1991): Large-scale thin-skinned tectonics in the eastern boundary of the Bohemian Massif. - Tectonics, $10,2,273-286$

Dvořák, J. (1994): Variský flyšový vývoj v Nízkém Jeseníku na Moravě a ve Slezsku. - Český geologický ústav, Praha.

Grygar, R. - Vavro, M. (1995): Evolution of Lugosilesian Orocline (north-eastern periphery of the Bohemian Massif): Kinematics of Variscan deformation. - Journal of the Czech Geological Society, 40, 1-2, 65-90.

Havír. J. (2001): Paleostress analysis in the Jakubčovice quarry (the Nízký Jeseníky Upland) - an example of results affected by folding. - Bulletin of the Czech Geological Survey, 76, 3, 169-177.

Havír, J. (2003): Geometrie strukturních prvků na jv. okraji Nízkého Jeseníku a ve kře Maleníku - předběžné výsledky (měření a analýzy v roce 2002). - MS, ČGS. Brno.

Havír, J. - Dvořák V. - Otava (2003): Nové výsledky strukturního studia Paleozoika okolí Hranic. - Geologické výzkumy na Moravě a ve Slezsku v roce 2002, 48-51.

Havír, J. - Gilíková H. (2007): Výsledky strukturního studia kulmských sedimentů v okolí Suchdolu nad Odrou. - Geologické výzkumy na Moravě a ve Slezsku v roce 2006, 52-55.

Havír, J. -Otava, J. (2004): Badenian deformations in Carpathian Foredeep; a case study from NE Moravia. - Scripta Facultatis Scienciae Naturalis Universitatis Masarykiensis Brunensis 31-32, Geology, 99-106.

Kodym, O. - Fusán, O. - Matějka, A. (1967): Geologická mapa ČSSR 1 : 500 000. - Ústřední ústav geologický, Praha.

Krejčí, O. - Hanžl, P. - Hubatka, F. - Sedlák, J. - Švancara, J. (2002): Hercynian and Alpine brittle deformation of the Bruno-Vistulicum and its sedimentary cover units in the footwall of the Outer Western Carpathians (E part of the Czech Republic). - Krystalinikum, 28, 145-167.

Kumpera, O. (1983): Geologie spodního karbonu jesenického bloku. - Knihovna Ústředního ústavu geologického, sv. 59, 172 pp. Mahel', M. - Púchy, R. - Varga, J. (1973): Tectonic map of the Carpathian-Balkan mountain system and adjacent areas 1:1000 000. - GUDŠ Bratislava/UNESCO Paris.

Otava, J. - Havíŕ, J. (2006): Apparent contradiction between tectonics and deposition in overturned strata - a case study from the "Moravian Culm" (Czech Republic). - Geological Qarterly, 50, 3, 391-396.

Roth, Z. (1990): Geologická mapa ČSSR 1 : 200 000, list M-33-XXIV Olomouc. - Ústřední ústav geologický Praha. 